
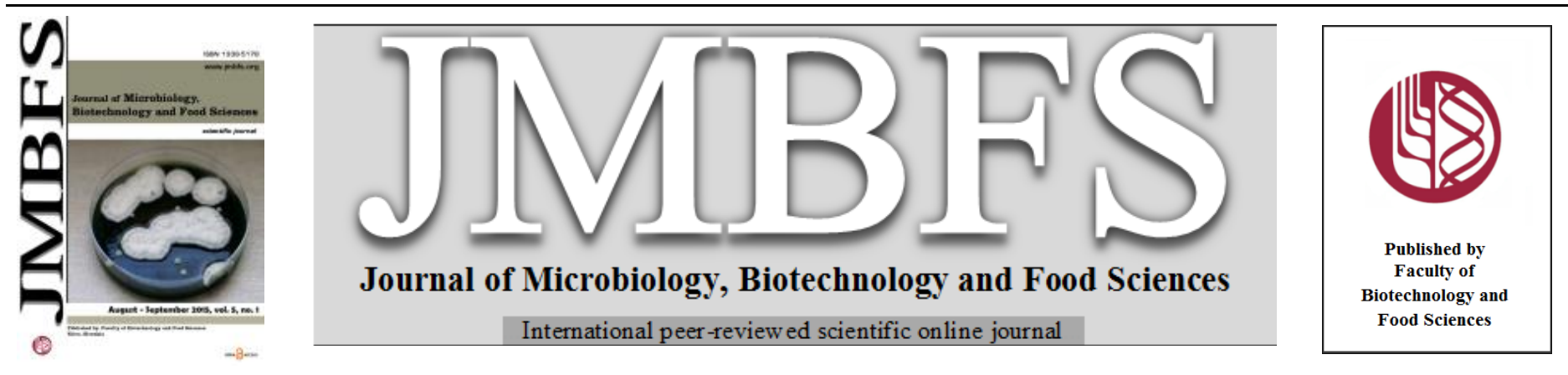

\title{
FAUNA, ECOLOGY AND TAXONOMY OF CYPRINIFORMES FISH HELMINTHS IN UZBEKISTAN
}

\author{
Erkinboy Shakarboev ${ }^{1}$, Feruza Safarova $^{2}$, Djalaliddin Azimov ${ }^{2}$, Axmet Urimbetov $^{1}$ \\ Address(es): \\ ${ }^{1}$ The Institute of the Gene Pool of Plants and Animals of Uzbek Academy of Sciences, Bagishamol, 232, 100053, Tashkent, Uzbekistan, +998712890465. \\ ${ }^{2}$ Tashkent State Agrarian University Nukus of Branch, Abdambetov, 361,230100, Nukus, Uzbekistan, +998612292509.
}

*Corresponding author: shakarboev@ rambler.ru

doi: $10.15414 / j m b f s .2015 .5 .1 .88-91$

\section{ARTICLE INFO}

Received 15. 7. 2015

Revised 30. 7. 2015

Accepted 31. 7. 2015

Published 1. 8. 2015

Regular article

OPEN $\partial_{\text {ACCESS }}$

\begin{abstract}
The purpose of the research was to study helminthofauna of fish Cypriniformes order in comparative aspect in artificial and natural water bodies and the clarification ways of formation of faunal assemblages and development of scientific bases of prevention of helminthiasis of fish. An extensive and systematic research of helminthofauna of fish water bodies of the order Cypriniformes of the northeast of Uzbekistan has realized and taxonomic and faunal analysis of detected parasites has also been carried out. Fauna of parasitic worms of Cypriniformes in ponds of diverse Syrdarya river shows 49 species, 18 species belongs to the class Trematoda, Cestoda class represents 13 species, class Acanthocephala 4 species and the class Nematoda 14 species. Analysis of biological properties and ecological specialty of Cypriniformes parasitic worms allows three types of helminth communities: 25 species parasitizing Cypriniformes as definitive hosts; 19 species parasitizing as intermediate hosts and 6 species parasitizing as a reservoir (paratenetic) hosts. Dioctophyme renale was registered first time in roach for the water bodies of the Syrdarya river. Ordinary carp, in our research, according to as host a new host Nematode of the Raphidascaris acus larvae. On the basis of factual data the environmental factors of the quantitative and qualitative composition of cyprinids helminthofauna in the northeast of Uzbekistan is reported.
\end{abstract}

Keywords: Helminths, trematode, cestode, nematode, acanthocephale, parasite fauna, ecology, taxonomy

\section{INTRODUCTION}

Helminths are certainly one of the most popular objects of study of the fauna of the Syrdarya River Basin. The Syrdarya River Basin is a natural geographic complex cross-border area, in which there is a variety of environmental conditions ponds. Currently, the Syrdarya basin has a high number of large reservoirs complexes that use hundreds of thousands hectares of area. Reservoirs are a new type of water bodies, characterized by specific and ecological conditions (Majumder et al., 2015; Casey et al., 2014; Jahantab et al., 2014). Due to intensive human activities related to the use of water resources, substantial qualitative and quantitative changes of biocenosis and the fish community has undergone. This inevitably of parasitic fish diseases leads to a decrease in the number of valuable species and the deterioration of the epizootic situation reservoirs. Parasitic diseases of fish not only cause significant economic losses associated with a decrease in fish productivity, but they are dangerous also to human health (Lopes et al., 2011; Osmanov 1975a). Information on the fauna of fish helminthes in the region are reflected in various studies (Artamoshin $\boldsymbol{e t}$ al., 1990; Osmanov, 1975a; Karimov, 2007). To date, data from previous researchers significantly out of date, confirmed recent resumption of studies helminthes of fauna of the region (Safarova et al., 2014; 2015). Based on the above it is actually a detailed study to ichthyic-parasitological of the current state of helminthes communities of their distribution within the various pools. The purpose of this study was to study of the helmintho-fauna of fish of the order of Cypriniformes in artificial and natural waters.

\section{MATERIAL AND METHODS}

Stationary studies were conducted in the period 2009-2014 in the water bodies of the Syrdarya basin (the Syrdarya River, the Chirchik River, Aydar-Arnasay lake system, Tuyabuguz reservoir and fish farms, "Balikchi", "Damachi" and
"Tashkent fish farm"), in Syrdarya, Tashkent and Djizakh region. Collection and study of helminths of fish were conducted using appropriated methods described by Jenkins et al. (1965) and Bykhovskaya-Pavlovskaya and Shcherbina (1985). In the study 2527 individuals of 15 species of Cypriniformes (Cyprinidae - 12, Cobitidae - 3) were analyzed. Besides, we carried out incomplete dissections of 1407 fish individuals and prepared 1561 temporary and permanent whole mounts. The cameral treatment and identification of Trematoda species was carried out at the Laboratory of General Parasitology of the Institute of Gene Pool of Plants and Animals of Uzbek Academy of Sciences. Helminth species were identified by using the Reference Guide of Freshwater Fishes (Tonguthai, 1997; Ieshko et al., 2012; Shigin, 1986; Khokhlova, 1986) and the Catalogues (Pugachev, 2002). The studies were conducted using a microscope type Olympus CK 2 (Olympus, Japan). The preparations were examined under the microscope LOMO MBI-3 and MBI-4 (Carl Zeiss, Germany), while the drawings were produced using the drawing tubes RA-4 and RA-5.

\section{RESULTS AND DISCUSSION}

Results of study detected, that the helminths of Cypriniformes from the basin of the Syrdarya (within Uzbekistan) currently present 49 species: 18 species of class Trematoda, 13 of Cestoda, 14 of Nematoda and 4 of Acanthocephala (Table 1) Class Trematoda represented in the studied basin 18 species belonging to the 5 orders and 9 families. The most numerous representatives were from order Strigeida. For class Cestoda representatives of the four orders - Caryophyllida, Pseudophyllida, Proteocephalida and Cyclophyllida were detected in the investigated region. There are 13 species found for Cypriniformes. The most widespread are the families Caryophyllaeidae (Leuckart, 1878) and Dilepididae (Fuhrmann, 1907) with four species each. 


\begin{tabular}{|c|c|c|c|}
\hline Class & Order & Family & Species \\
\hline \multirow{9}{*}{ Trematoda } & Sanguinicolida & Sanguinicolidae & Sanguinicola inermis Plehn, 1905 \\
\hline & Clinostomida & Clinostomidae & Clinostomum complanatum Rud., 1819 \\
\hline & \multirow{4}{*}{ Fasciolida } & Gorgoderidae & Phyllodistomum elongatum Nybelin, 1926 \\
\hline & & Orientocreadiidae & Orientocreadium siluri Bychowsky et Dubinina, 1954 \\
\hline & & Allocreadiidae & Allocreadium isoporum Looss, $1894 ;$ A. transversale Rudolphi, 1802 \\
\hline & & Monorchidae & Asymphylodora kubanicum Issaitschikoff, 1923 \\
\hline & \multirow[t]{2}{*}{ Strigeiida } & Diplostomidae & $\begin{array}{l}\text { Diplostomum spathaceum (Rud., 1819); Tylodelphys clavata (Nordmann, 1832); Bolboforus } \\
\text { confusus (Krause, 1914); Hysteromorpha triloba Rudolphi, 1819; Conodiplostomum perlatum } \\
\text { Ciurea, 1911; Ornithodiplostomum scardinii (Schulman, 1952); Posthodiplostomum cuticola } \\
\text { Nardmann, 1832; P. brevicaudatum Nordmann, } 1832\end{array}$ \\
\hline & & Strigeidae & Apharyngostrigea cornu Zeder, 1800; A. sogdiana Pavlowsky et Anitschkov, 1923 \\
\hline & Bucephalida & Bucephalidae & Rhipidocotyle campanula Dujardin, 1845 \\
\hline \multirow{6}{*}{ Cestoda } & Caryophyllidea & Caryophyllaeidae & $\begin{array}{l}\text { Caryophyllaeus laticeps Pallas, 1781; C. fimbriceps Annenkova-Chlopina, 1919; } \\
\text { Biacetabulum appendiculatum Szidat, 1937; Khawia sinensis Hsü, } 1935\end{array}$ \\
\hline & \multirow{3}{*}{ Pseudophyllidea } & Amphicotylidae & Bathybothrium rectangulum Bloch, 1782 \\
\hline & & Bothriocephalidae & Bothriocephalus opsariichthydis Yamaguti, 1934 \\
\hline & & Ligulidae & Ligula intestinalis Linnaeus, 1758; Digramma interrupta Cholodkovsky, 1914 \\
\hline & Proteocephalidea & Proteocephalidae & Proteocephalus torulosus Batsch, 1786 \\
\hline & Cyclophyllidea & Dilepididae & $\begin{array}{l}\text { Paradilepis scolecina Rudolphi, 1819; Gryporhynchus cheilancristrotus Wedl, 1955; G. } \\
\text { pusillus Nordman, 1832; Dilepis unilateralis Rudolphi, } 1819\end{array}$ \\
\hline \multirow{8}{*}{ Nematoda } & Trichocephalida & Capillariidae & Capillaria tomentosa Dujardin, 1843 \\
\hline & Dioctophymida & Dioctophymidae & Dioctophyme renale Goeze, 1782 \\
\hline & \multirow{5}{*}{ Spirurida } & Rhabdochonidae & Rhabdochona denudata Dujardin, 1845; R. gnedini Skrjabin, 1946 \\
\hline & & Desmidocercidae & Desmidocercella numidica Seurat, 1920 \\
\hline & & Gnathostomidae & Gnathostoma hispidum Fedtschenko, 1872 \\
\hline & & Camallanidae & Camallanus truncatus Rudolphi, 1814 \\
\hline & & Philometridae & $\begin{array}{l}\text { Philometra ovata Zeder, 1803; Ph. abdominalis Nybelin, 1928; Ph. intestinalis Dogiel et } \\
\text { Bychowsky, } 1934\end{array}$ \\
\hline & Ascaridida & Anisakidae & $\begin{array}{l}\text { Contracaecum spiculigerum Rudolphi, } 1809 ; \quad \text { C. microcephalum Rudolphi, 1819; } \\
\text { Porrocaecum reticulatum Linstow, 1890; Raphidascaris acus Bloch, } 1779\end{array}$ \\
\hline \multirow{3}{*}{ Acanthocephala } & Neoacanthocephala & Neoechinorhynchidae & Neoechinorhynchus rutili Müller, 1780 \\
\hline & \multirow{2}{*}{ Echinorhynchida } & Pomphorhynchidae & Pomphorhynchus laevis Müller, 1776 \\
\hline & & Echinorhynchidae & Acanthocephalus lucii Müller, 1776; A. anguillae Müller, 1780 \\
\hline
\end{tabular}

Other orders were represented by one or two common helminths species of Cypriniformes. Worthy of note are the findings of Dioctophyme renale Goeze, 1782 larvae III in Cypriniformes in the studied region. Previously this species were reported in many fish inhabiting water bodies along the Amydarya River and in the lower reaches of the Syrdarya River (Spasskii, 1987; Osmanov, 1975 a,b). The greatest diversity of species of worms turned Syrdarya River waters (39), followed by the Chirchik River (15). The lowest number of helminths was recorded in the Aidar-Arnasay lake system (AALS), where only eight helminth species were found: 3 Trematodes, 2 Cestodes and 3 Nematodes. In our opinion, this is connected with peculiar ecological conditions in different water bodies (Table 2). Ten helminth species were found in the fish farms. At the same time prevalence and intensity of invasion varies widely.
Among of the registered helminths often frequently recorded pathogen species were Sanguinicola inermis Plehn, 1905, Diplostomum spathaceum Rudolphi, 1819, Tylodelphys clavata Nordmann, 1832, Khawia sinensis Hsü, 1935 Bothriocephalus opsariichthydis Yamaguti, 1934, Ligula intestinalis Linnaeus, 1758 larvae, Digramma interrupta Rudolphi, 1810 larvae and Raphidascaris acus Bloch, 1779 larvae. The poor diversity of the parasite fauna in Cypriniformes in landlocked water bodies and an almost complete absence of a number of specific parasites are undoubtedly associated with the process of acclimatization, where natural processes of the formation of respective groups of considered helminth hosts were disturbed.

Table 2 Distribution of helminths of Cypriniformes in the north-east of Uzbekistan (2009 - 2014)

\begin{tabular}{|c|c|c|c|c|c|c|c|c|c|c|c|c|}
\hline \multirow[t]{2}{*}{ Species } & \multicolumn{3}{|c|}{$\begin{array}{c}\text { Mid-course of the } \\
\text { Syrdarya River }(n=600)\end{array}$} & \multicolumn{3}{|c|}{ Chirchik River $(\mathrm{n}=547)$} & \multicolumn{3}{|c|}{$\begin{array}{l}\text { Aidar-Arnasay lake } \\
\text { system }\end{array}$} & \multicolumn{3}{|c|}{ Fish farms $(\mathrm{n}=564)$} \\
\hline & A & B & $\mathrm{C}$ & A & B & $\mathrm{C}$ & A & B & $\mathrm{C}$ & A & B & $\mathrm{C}$ \\
\hline Sanguinicola inermis Plehn, 1905 & 1.8 & 14.8 & 0.27 & - & - & - & - & - & - & - & - & - \\
\hline Clinostomum complanatum Rud., 1819 & - & - & - & 2.0 & 15.5 & 0.31 & - & - & - & 2.1 & 16.1 & 0.34 \\
\hline Phyllodistomum elongatum Nybelin, 1926 & - & - & - & - & - & - & - & - & - & 1.0 & 14.8 & 0.15 \\
\hline Orientocreadium siluri Bychowsky et Dubinina, 1954 & - & - & - & 1.0 & 26.8 & 0.29 & - & - & - & - & - & - \\
\hline Allocreadium isoporum Looss, 1894 & 0.83 & 31.6 & 0.26 & 0.91 & 33.4 & 0.30 & - & - & - & - & - & - \\
\hline A. transversale Rudolphi, 1802 & 2.0 & 16.5 & 0.33 & - & - & - & - & - & - & - & - & - \\
\hline Asymphylodora kubanicum Issaitschikoff, 1923 & 1.1 & 26.5 & 0.31 & - & - & - & - & - & - & - & - & - \\
\hline Diplostomum spathaceum (Rud., 1819) & 2.6 & 14.4 & 0.38 & 2.1 & 17.4 & 0.38 & 1.5 & 19.0 & 0.30 & 1.9 & 17.0 & 0.33 \\
\hline Tylodelphys clavata (Nordmann, 1832) & 1.5 & 21.8 & 0.32 & - & - & - & - & - & - & - & - & - \\
\hline Bolboforus confusus (Krause, 1914) & - & - & - & 2.9 & 14.0 & 0.41 & - & - & - & - & - & - \\
\hline Hysteromorpha triloba Rudolphi, 1819 & - & - & - & - & - & - & 0.49 & 30.7 & 0.15 & - & - & - \\
\hline Conodiplostomum perlatum Ciurea, 1911 & - & - & - & - & - & - & 2.5 & 14.0 & 0.36 & - & - & - \\
\hline Ornithodiplostomum scardinii (Schulman, 1952) & - & - & - & 2.0 & 18.6 & 0.37 & - & - & - & - & - & - \\
\hline Posthodiplostomum cuticola Nardmann, 1832 & 2.5 & 15.1 & 0.37 & - & - & - & - & - & - & - & - & - \\
\hline P. brevicaudatum Nordmann, 1832 & - & - & - & 1.64 & 20.7 & 0.34 & - & - & - & - & - & - \\
\hline Apharyngostrigea cornu Zeder, 1800 & - & - & - & 2.1 & 18.0 & 0.39 & - & - & - & - & - & - \\
\hline A. sogdiana Pavlowsky et Anitschkov, 1923 & 2.1 & 16.0 & 0.34 & - & - & - & - & - & - & - & - & - \\
\hline Rhipidocotyle campanula Dujardin, 1845 & 1.5 & 20.6 & 0.31 & - & - & - & - & - & - & 1.2 & 24.2 & 0.30 \\
\hline Caryophyllaeus laticeps Pallas, 1781 & 1.2 & 11.0 & 0.13 & - & - & - & - & - & - & - & - & - \\
\hline C. fimbriceps Chlopina, 1919 & 12.3 & 6.0 & 0.74 & - & - & - & - & - & - & 10.4 & 6.5 & 0.67 \\
\hline Biacetabulum appendiculatum Szidat, 1937 & 3.0 & 6.0 & 0.18 & - & - & - & - & - & - & - & - & - \\
\hline Khawia sinensis Hsü, 1935 & 2.5 & 6.6 & 0.16 & 2.4 & 6.7 & 0.15 & - & - & - & 2.5 & 6.6 & 0.16 \\
\hline Bathybothrium rectangulum Bloch, 1782 & - & - & - & 20.0 & 4.2 & 0.84 & - & - & - & 20.0 & 4.2 & 0.84 \\
\hline Bothriocephalus opsariichthydis Yamaguti, 1934 & 4.1 & 5.4 & 0.22 & 4.4 & 5.1 & 0.22 & - & - & - & - & - & - \\
\hline Ligula intestinalis Linnaeus, 1758 & 9.3 & 7.1 & 0.66 & 11.5 & 6.4 & 0.73 & 38.3 & 1.6 & 0.63 & 11.5 & 6.3 & 0.73 \\
\hline
\end{tabular}




\begin{tabular}{|c|c|c|c|c|c|c|c|c|c|c|c|c|}
\hline Digramma interrupta Cholodkovsky, 1914 & 17.6 & 4.2 & 0.74 & 16.8 & 4.3 & 0.80 & - & - & - & 9.5 & 6.4 & 0.61 \\
\hline Paradilepis scolecina Rudolphi, 1819 & 7.8 & 4.6 & 0.36 & - & - & - & - & - & - & - & - & - \\
\hline Gryporhynchus cheilancristrotus Wedl, 1955 & 15.3 & 5.0 & 0.76 & - & - & - & - & - & - & - & - & - \\
\hline G. pusillus Nordman, 1832 & 8.1 & 6.2 & 0.51 & - & - & - & - & - & - & - & - & - \\
\hline Capillaria tomentosa Dujardin, 1843 & 15.3 & 5.0 & 0.77 & - & - & - & - & - & - & - & - & - \\
\hline Dioctophyme renale Goeze, 1782 & 8.8 & 6.5 & 0.57 & - & - & - & 8.7 & 6.2 & 0.54 & - & - & - \\
\hline Rhabdochona denudata Dujardin, 1845 & 8.8 & 6.3 & 0.55 & 7.3 & 6.9 & 0.50 & - & - & - & - & - & - \\
\hline Camallanus truncatus Rudolphi, 1814 & 15.8 & 3.2 & 0.51 & - & - & - & - & - & - & - & - & - \\
\hline Philometra ovata Zeder, 1803 & 15.3 & 4.6 & 0.71 & - & - & - & - & - & - & - & - & - \\
\hline Ph. abdominalis Nybelin, 1928 & 15.3 & 3.5 & 0.54 & - & - & - & - & - & - & - & - & - \\
\hline Ph. intestinalis Dogiel et Bychowsky, 1934 & 10.3 & 4.2 & 0.43 & - & - & - & - & - & - & - & - & - \\
\hline Contracaecum spiculigerum Rudolphi, 1809 & 13.1 & 3.5 & 0.47 & - & - & - & - & - & - & - & - & - \\
\hline C. microcephalum Rudolphi, 1819 & 9.3 & 5.5 & 0.51 & - & - & - & 25.9 & 1.9 & 0.51 & - & - & - \\
\hline A. anguillae Müller, 1780 & 5.5 & 4.3 & 0.23 & - & - & - & - & - & - & - & - & - \\
\hline
\end{tabular}

$\mathrm{A}$ - prevalence (\%); B - intensity; $\mathrm{C}-$ abundance

Obtained data on the quantitative composition of helminth fauna of the Cypriniformes and their biological characteristics make it possible to allocate three types of communities: helminths parasitizing Cypriniformes as definitive hosts; helminths parasitizing Cypriniformes as intermediate hosts and helminths parasitizing Cypriniformes as a reservoir (=paratenetic) hosts. The distribution of indicated helminth communities in the region depends on a number of wellknown biotic and abiotic factors. The first type includes 25 helminth species: 7 Trematodes, 7 Cestodes, 11 Nematodes and 4 Acanthocephalans (Table 3). Fish are infected here mainly through the digestive tracts of hosts, as well as directly by a free-swimming nematode larvae (Capillaria tomentosa Dujardin, 1843) and penetration of trematode cercariae (Sanguinicola inermis Plehn, 1905) through the cover of cypriniform fish. But the life cycle of Capillaria tomentosa is studied insufficiently. Possible participation of Oligochaeta in the life cycle of these Nematodes in experiments requires additional studies (Moravec, 1994)

There is no uniform opinion regarding the participation of different categories of hosts (both intermediate and paratenic) in the recorded Nematodes of the family Anisakidae Skrjabin et Karokhin, 1945: Raphidascaris acus (Bloch, 1779), Porrocaecum reticulatum (Linstow, 1890), Contracaecum spiculigerum (Rudolphi, 1809) and C. microcephalum (Rudolphi, 1819) (Faltýnková et al., 2014; Mozgovoy and Kosinova, 1963). Nevertheless, we find acceptable data as (Faltýnková et $\boldsymbol{a l} .$, 2014) considering Cypriniformes as second intermediate hosts of Raphidascaris acus.

Table 3 Biological characteristics of helminths of Cypriniformes in the studied region

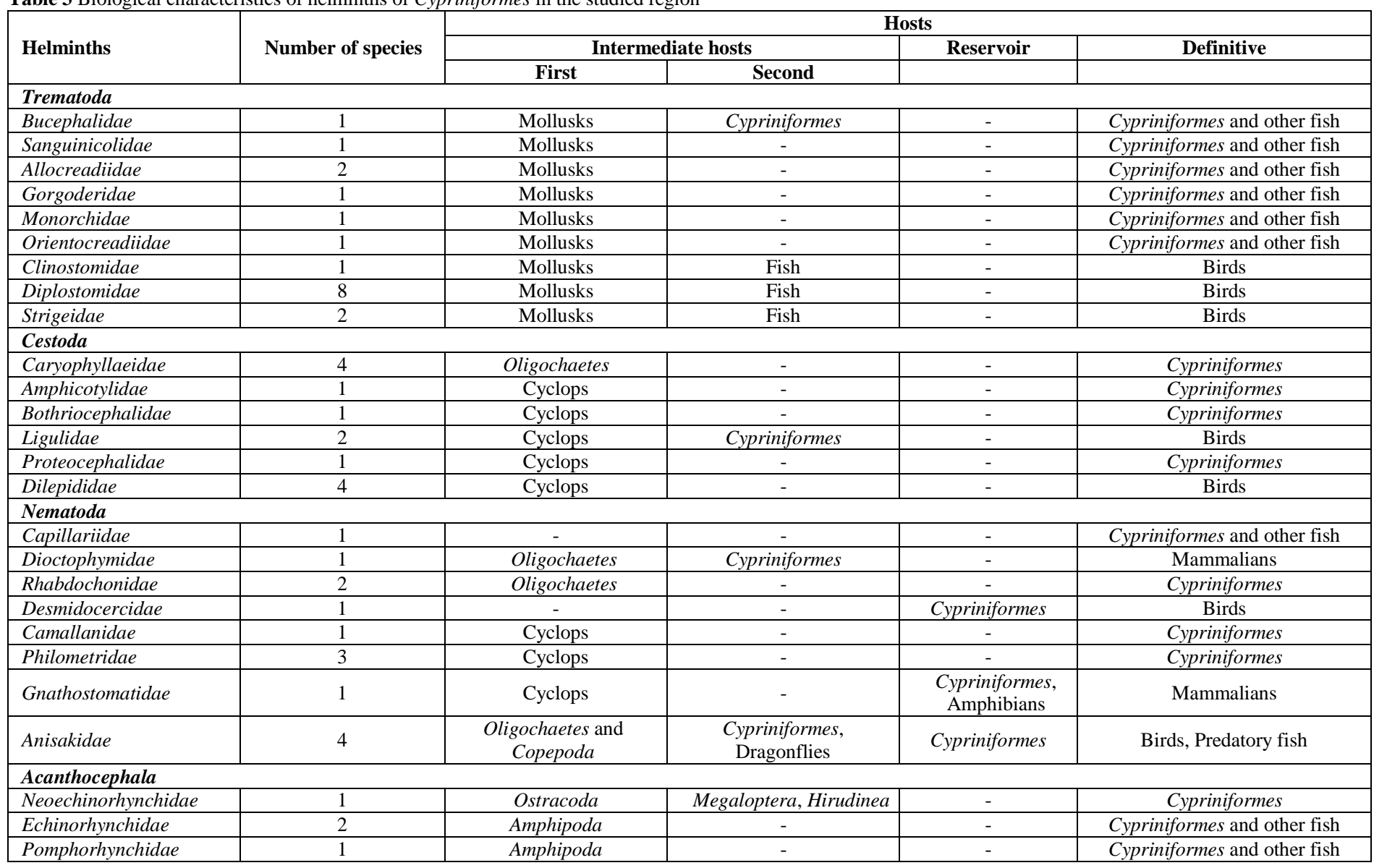


This study also reports a corresponding view for the species of Porrocaecum and Contracaecum. The second type is characterized by the fact that some species of Cypriniformes are the second intermediate hosts for nineteen helminth species: 12 Trematodes, 2 Cestodes and 5 Nematodes. Definitive hosts (predatory fish, fish-eating birds and mammalians) are infected consuming Cypriniformes fish infected by helminth larvae.

Participation of Cypriniformes as paratenic hosts in the transmission of the considered helminths is in many respects questionable. Nevertheless, Cypriniformes were previously noted as paratenetic hosts (Dorovskikh and Stepanov, 2014). According to our findings, they are noted for two Nematoda species of the genera Desmidocercella and Gnathostoma, which should be assigned to the third type. Our results also confirm that Cypriniformes in the studied region promote the circulation of a number of Cestoda, Trematoda, Nematoda and Acanthocephala species in predatory fishes, birds and mammalians (Table 3 ).

Distribution of helminths of Cypriniformes in some parts of the Syrdarya River basin is not equivalent. The optimal conditions for the functioning of the communities of helminths obviously represented in the reservoirs of the middle reaches, where 49 species of parasites were recorded. In the 60 years of the last century, in this region have been reported 20 species of helminths (Osmanov 1975b). In other parts of the Syrdarya significantly fewer species were noted, 25 - in the lower reaches (Artamoshin et al., 1990) and 10 - in the headwaters (Spasskii, 1987; Gehring et al., 2014).

\section{CONCLUSION}

Results of this research show that the qualitative and quantitative distribution of Cypriniformes helminths in water bodies of the basin of the Syrdarya River is very uneven. The greatest diversity of species is characterized by well warmed water bodies in coastal parts of the river. There are optimal conditions for the development of Cypriniformes parasites that attract birds and mammals involved in the circulation of helminths. The life cycle of Capillaria tomentosa is studied insufficiently. Possible participation of Oligochaeta in the life cycle of Nematodes require additional studies. Species diversity of Cypriniformes helminths in the investigated region is rich enough and stable functions in water biocenosis. The parasitic worms include 49 species of Cypriniformes: 18 species of Trematoda, 13 of Cestoda, 14 of Nematoda and 4 of Acanthocephala. Among the species mentioned most common pathogenic representatives are those of the family Sanguinicolidae, Diplostomidae, Bothriocephalidae, Ligulidae and Anisakidae, whith a negative effect on the development of hamper the fishing industry. This fact dictates conduct of involves constant monitoring of ichthyoparasitological situation in specific natural and artificial water bodies of Uzbekistan.

Acknowledgments: We are very grateful to Department of Bio-ecology of the Far Eastern State Technical University and T.E. Butorina Ph.D. for advice in determining Cypriniformes fish helminth.

\section{REFERENCES}

ARTAMOSHIN, A.S., KHODAKOVA, V.I., FROLOVA, A.A. MELESHCHENKO, K.P. 1990. Fishes in the lower reaches of the Ob River studied for their infectiousness with helminth larvae of medical significance. Meditsinskaia Parazitologiia i Parazitarnye Bolezni (Moscow), 1, 40-41. BYKHOVSKAIA-PAVLOVSKAIA, I.E., SHCHERBINA, V.P. 1985. Contribution of Soviet parasitologists to the victory over fascist Germany. Parazitologiia, 19(5), 410-414.

ASEY, J.M., AINSWORTH, T.D., CHOAT, J.H., CONNOLLY, S.R.. 2014 Farming behaviour of reef fishes increases the prevalence of coral disease associated microbes and black band disease. Proceedings of the Royal Society B: Biological Sciences, 281(1788), 1032. http://dx.doi.org/10.1098/rspb.2014.1032 DOROVSKIKH, G.N., STEPANOV, V.G. 2014. Seasonal dynamics of the parasite fauna and of the component community structure ofparasites of the minnow Phoxinus phoxinus (L.) from the Pechora River. Parazitologia, 48(1), 54-62.

FALTÝNKOVÁ, A., GEORGIEVA, S., KOSTADINOVA, A., BLASCOCOSTA, I., SCHOLZ, T., SKIRNISSON, K.. 2014. Diplostomum von Nordmann 1832 (Digenea: Diplostomidae) in the sub-Arctic: descriptions of the larval stages of six species discovered recently in Iceland. Systematic Parasitology, 89(3), 195-213. http://dx.doi.org/10.1007/s11230-014-9517-0

GEHRING, C A., MUELLER, R.C., HASKINS, K.E., RUBOW, T.K., WHITHAM, T.G. 2014. Convergence in mycorrhizal fungal communities due to drought, plant competition, parasitism, and susceptibility to herbivory: consequences for fungi and host plants. Frontiers in Microbiology, 25 (5), 306. http://dx.doi.org/10.3389/fmicb.2014.00306

IESHKO, E.P., ANIKIEVA, L.V., LEBEDEVA, D.I., ILMAST, N.V. 2012. Population biology of Cestode genus Triaenophorus in natural and manmade waterbodies. Parazitologia, 46(6), 434-443.

JAHANTAB, M., HASELI, M., SALEHI, Z. 2014. Morphological and genetic characteristics of the anisakid nematode Raphidascaris acusfrom the southwest
Caspian Sea: evidence for the existence of sibling species within a species complex. Parasitological Research, 113(9), 3419-3425. http://dx.doi.org/10.1007/s00436-014-4007-5 JENKINS, E.J., SCHURER, J.M. GESY, K.M. 2011. Old problems on a new playing field: Helminth zoonoses transmitted among dogs, wildlife, and people in a changing northern climate. $\begin{array}{lll}\text { Veterinary } & \text { Parasotology, } & \text { 182(1), }\end{array}$ http://dx.doi.org/10.1016/j.vetpar.2011.07.015

KARIMOV, K.S., QAZI, I., KHAN, T.A., DRAPER, P.H., KHALID, F.A., MAHROOF-TAHIR, M. 2008. Humidity and illumination organic semiconductor copper phthalocyanine sensor for environmental monitoring. Environmental Monitoring and Assessment, 141(1-3), 323-328. http://dx.doi.org/10.1007/s10661-007-9898-5

KHOKHLOVA, I.G. 1986. Acanthocephalans of the terrestrial vertebrate animals in the fauna of the USSR. Moscow Nauka, 276, 100-110.

LOPES. L.P., PIMPÃO, D.M., TAKEMOTO, R.M., MALTA, J.C., VARELLA, A.M. 2011. Hysterothylacium larvae (Nematoda, Anisakidae) in the freshwater mussel Diplodon suavidicus (Lea, 1856) (Mollusca, Unioniformes, Hyriidae) in Aripuanã River, Amazon, Brazil. Journal of $\begin{array}{llll}\text { Invertebrates } & \text { Pathology, } & \text { 106(3), } & 357-359\end{array}$ http://dx.doi.org/10.1016/j.jip. 2010.12.002

MAJUMDER, S., PANDA, S., BANYOPADHYAY, M. 2015. Effect of temperature on the prevalence of different parasites in Cirrhinus mrigala Hamilton of West Bengal. Journal of Parasitic Diseases, 39(1), 110-112. http://dx.doi.org/10.1007//12639-013-0295-4

MORAVEC, F. 1994. Parasitic nematodes of freshwater fishes of Europe. Kluwer Academic Publishers, Prague, 473. ISBN 0-7923-2172-3

MOZGOVOY, A.A., KOSINOVA V.G. 1963. The study of the cycle of development in Raphidascaris acus (Bloch, 1799). The Proceedings of the Scientific Conference of All-Union Society of Helminthologists: Abstracts of reports. Moscow, 124-127.

OSMANOV, S.O. 1975. On the forthcoming scientific-industrial conference on the Aral. The Bulletin of the Karakalpak Branch of the Academy of Sciences of UzSSR. Nukus, 4, 40-43.

OSMANOV, S.O. 1975. To the knowledge of fish parasites of the river Syr Darya. Proceeding: Biology the Basis of Fish Farms Water Bodies in Central Asia and Kazakhstan. Alma-Ata:Nauka, 98-100.

SAFAROVA, F.E., SHAKARBAEV U.A., AKRAMOVA F.D., GOLOVANOV V.I. 2014. Fauna, peculiarities of distribution and ecology of trematodes in Cypriniformes fishes inhabiting waterbodies in the floodplain of the river Syrdarya. Journal of Russian Parasitology. Moscow, 1, 44-48.

SAFAROVA, F.E., AKRAMOVA, F.D., AZIMOV, D.A., GOLOVANOV, V.I., SHAKARBOEV, E.B. 2015 endohelminths of Cypriniform fish from waterbodies of the Syrdarya river: Fauna and distribution. Vestnik zoologii, 49(1), 67-74.

SHIGIN, A.A. 1986. Trematodes in the fauna of the USSSR: the genus Diplostomum, Metacercariae. Moscow Nauka, 253, 170-176.

SPASSKII, A.A. 1987. Improved methods for the helminthological autopsy of wild animals. Parazitologiia, 21(5), 643-647.

TONGUTHAI, K. 1997. Control of freshwater fish parasites: a Southeast Asian perspective. International Journ 